\title{
Micromycetes on Pisum sativum var. arvense
}

\author{
JOANNA MARCINKOWSKA
}

\author{
Department of Plant Pathology. Warsaw Agriculture University \\ 02-787 Warsaw, Nowoursynowska 166, Poland
}

M a r ink owska J: Mieromycetes on Pisum sativum var, arvense. Acta Mycol. 32 (1): $31-39,1997$.

Seeds of 11 Austrian winter pea genotypes, harvested at Radzików (CEP) in 1993 and 1994, were evaluated for fungi occurrence on Coon's agar medium in Petri plates. Number of species isolated depended on the genotype and year of collection. Alternaria alternata, Stemphylitam botryosum were found on all the tested samples and Phoma pinodella and Fusarium poae were also common while Botrytis cinerea. Sclerotinia sclerotiorum and Mycosphaerella pinodes appeared to be common only in 1993. Three species occurred only once. The mycoflora was richer in 1993. The common seed inhabitants usually transmitted higher percentage of fungi than species occuring more seldom.

Key words: micromycetes on Pisum sativum.

\section{INTRODUCTION}

Several studies were conducted with Pisum sativum L. seed mycoflora of spring-planted peas ( $\mathrm{M}$ a r c i n k o w s k a 1998). Some authors ( $\mathrm{S} \mathrm{k} \mathrm{o} \mathrm{-}$ $1 \mathrm{ko}$ et al. 1954; T r u sz kow s a et al. 1968; C z y ż e w s k a 1976; Filipowicz 1976) investigated not only pathogenic fungi but also saprotrophic ones as the latter might cause seed destruction, thus decreasing plant stands (F ilipowicz 1976; M a r cinkowska, Schollenberger 1979). Recently Polish plant breeders at Radzików (personal communication) have bred a few lines of fall-planted Austrian winter pea, Pisum sativum L. var. arvense (L.) Poir.

The objective of this study was to describe all the fungi transmitted by seeds of the newly introduced pea crop into Poland in order to become acquainted with the total spectrum of fungi occurring in the above environment. 


\section{MATERIAL AND METHODS}

Seeds were harvested at Radzikow (Central-East Poland $=$ CEP) in the Plant Breeding and Acclimatization Institute at Radzików from Austrian winter pea plots. In 1993 one cultivar and 7 breeding lines (Table 1) were evaluated while in 1994 the same cv. Melrose and 2 breeding lines R 1 and R 2 were tested along with 3 new lines (Table 2). Agar plate method with Coon's (CN) medium (Ali et al. 1978) in Petri plate ( $\mathrm{Pp}$ ) $10 \mathrm{~cm}$ diameter was used. Twelve surface sterilized seeds, following K e r r's (1963) procedure, were placed in a $\mathrm{Pp}$. A set of a sample contained 204 seeds (17 Pp $\times 12$ sds). A whole sample comprised 408 seeds. Seed samples were divided to be evaluated at different time, the first set in the late fall and the second one in the middle of winter. The same incubation conditions were provided for seeds of both sets (M a r c i n k o w s k a 1997). Readings were taken on the eighth day since planting.

The keys of Ellis (1971); Arx (1974), B o oth (1977) and CMI Descriptions and the paper ( $\mathrm{N}$ o o r d e l o o s et al. 1993) were used for fungi identification.

Data were statistically evaluated with Statgraphics Plus programme. Fungi frequency on seeds after percentage data transformation was evaluated by analysis of variance using $F$ test and means were separated with Tukey multiple range test.

\section{RESULTS}

Austrian winter pea seeds harvested in 1993 transmitted higher number of fungi species than those of 1994, respectively 20 and 16. The last year 6 genotypes were evaluated while in $1993-8$ ones (Tables 1-2). The three genotypes studies both years showed more numerous fungal species occurrence in 1993. Apart from the number of species the percentage of seeds occupied by the fungi was also higher in 1993 than in 1994, as well as for cv. Melrose and lines R 1, R 2, but these differences were statistically non-significant (Table 3). Alternaria alternata and Stemphylium botryosum were the only species which occurred on all the seed samples tested in 1993 and 1994 (Tables 1-2). Phoma pinodella and Fusarium poae (absent on one and two out of 14 samples, respectively) were the next common inhabitants of the seeds. Sclerotimia sclerotiorum and Botrytis cinerea occurred on majority of samples (7/8) in 1993 but on half of them $(3 / 6,2 / 6)$ in 1994. Ascochyta pisi and Mycosphaerella pinodes were also noted less frequently in 1994. The other 12 species were isolated from less than a half of the samples but 3 of them ( $F$, oxysporum, Trichothecium roseum, Ulocladium consortiale) occurred only once. 


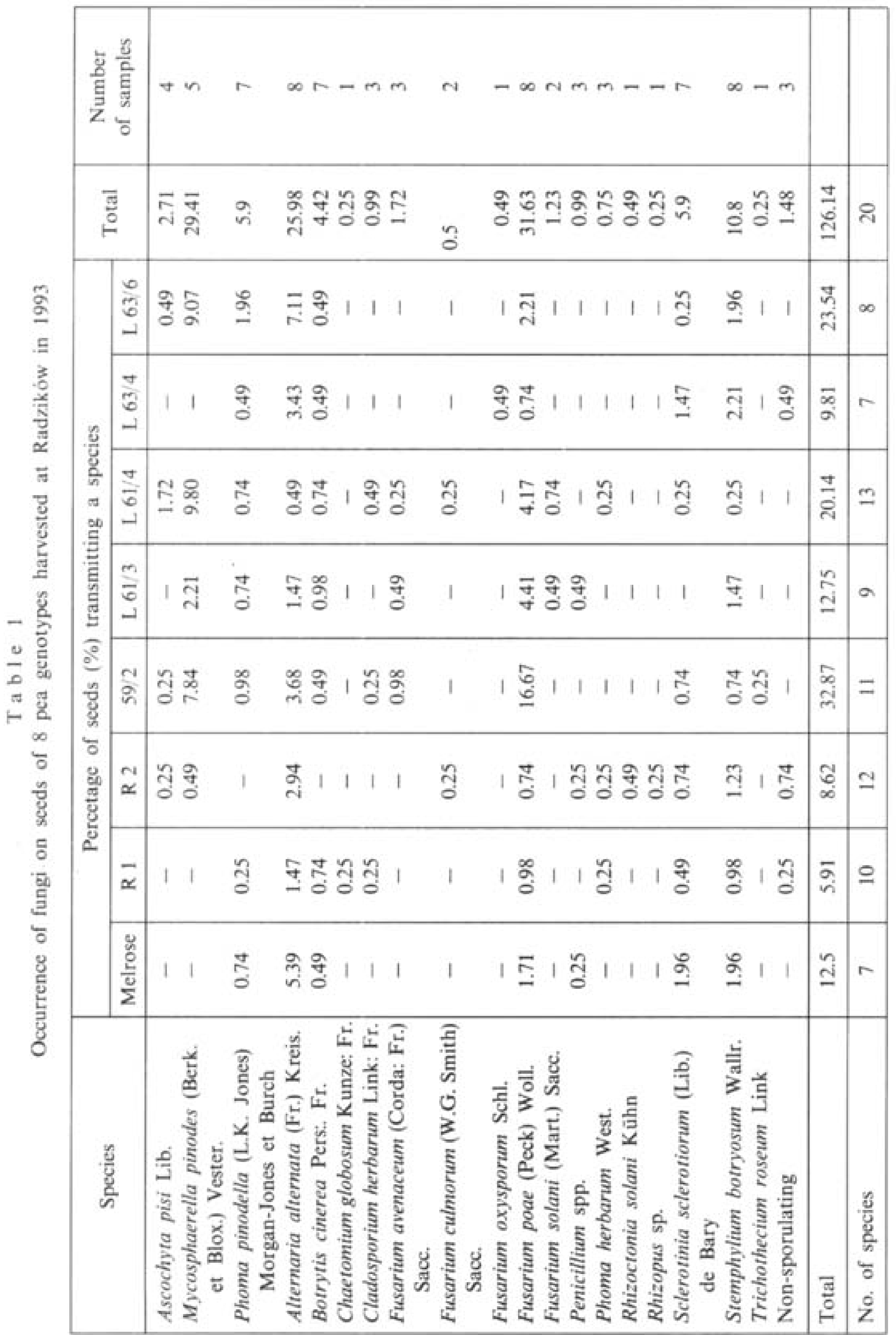


J. Marcinkowska

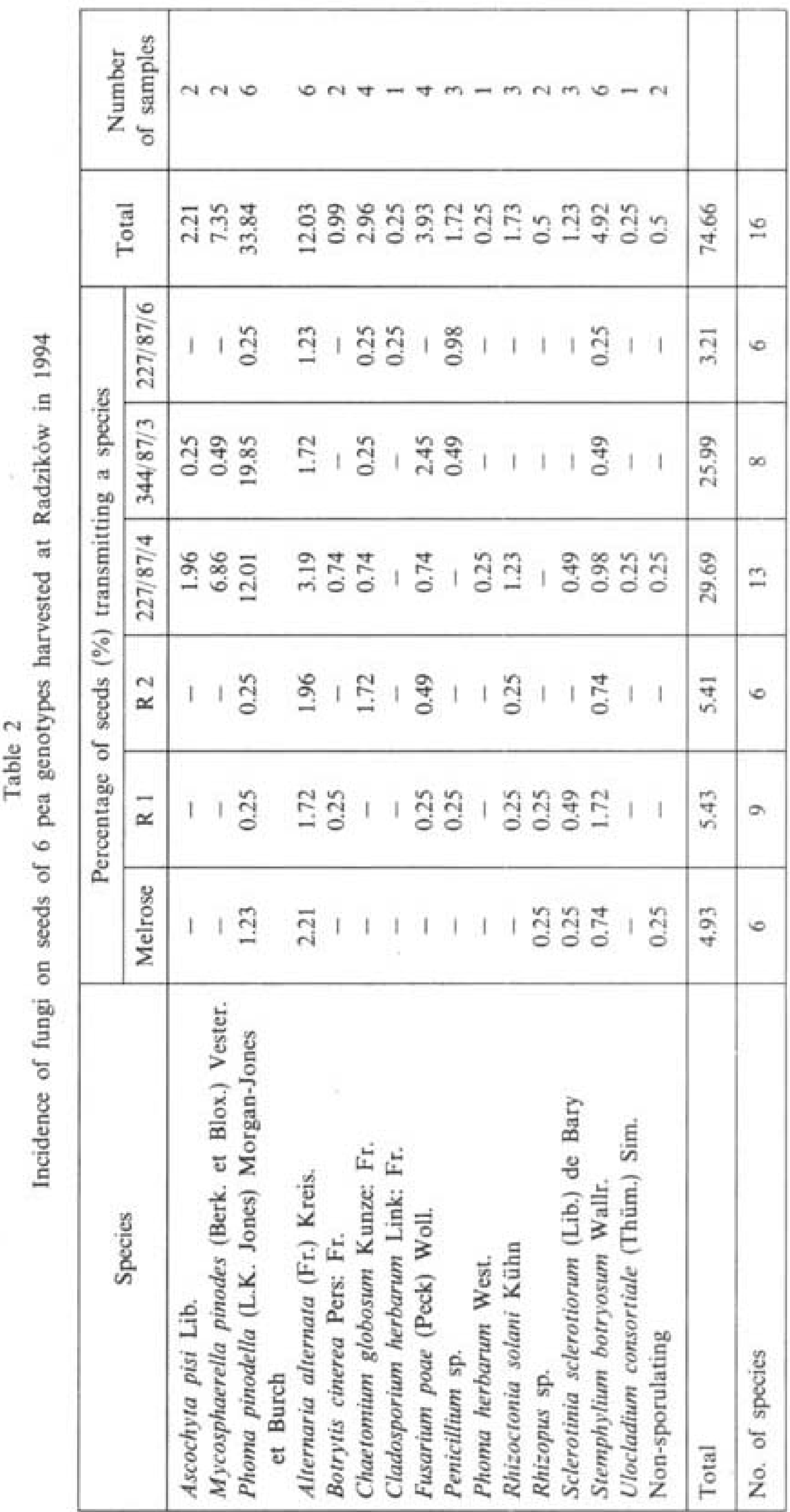


The variation of fungal occurence was also manifested in the percentage of species transmission. In $1993 F$. poae $(31.63), M$. pinodes $(29.41)$ and $A$. alternata (25.98) inhabited the highest percentage of seeds, while Chaetomium globosum. T. roseum and Rhizopus sp. only $0.25 \%$. P. pinodella was the most frequently occurring fungus (33.84) in 1994, being isolated almost 3 times as often as $A$. alternata (12.03) while Cladosporium herbarum and $U$. consortiale occurred on only $0.25 \%$ of seeds. The differences in fungal transmission were noted as well between genotypes. However, statistical differences were marked in a few cases, such as total of $A$. pisi, $M$. pinodes and $P$. pinodella, the species responsible for ascochyta blight disease' and separately $P$. pinodella (Table 3 ). In both cases line R 1 was the slightest inhabited but the lines $227 / 87 / 4$ and $344 / 87 / 3$ were the most infected. When the total percentage of pea pathogens (A. pisi, $M$, pinodes, $P$. pinodella, $B$. cinerea, $F$, oxysporum, $F$, solani., Rhizoctonia solani, S. sclerotiorum) was considered statistical differences were found, line 227/87/6 being inhabited the least and the highest one 227/87/4 (Table 3). Statistically significant differences were also found for the species of Fusarium and F. poae most commonly occurring among the genera (Table 3 ). Line 227/87/6 was not inhabited by Fusarium spp. but line 59/2 transmitted the highest percentage of $F$. poae whereas line 63/4 the lowest percentage. No statistical differences existed between genotypes in their ability for $A$. alternaria, B. cinerea and $S$. sclerotiorum transmission.

\section{DISCUSSION}

Austrian winter pea seed mycoflora was investigated in the same way as it was done for dry pea seeds (M a r c i n k o w s k a 1998). The agar plate method recommended by several laboratories ( $\mathrm{H}$ e w e $\mathrm{t} t$ 1987) was effective here. $\mathrm{CN}$ agar was used instead of PDA (G r z e I a k, I f la k ow i c z 1973) or MA ( $\mathrm{H}$ e w e t t 1987) because of very good fungi sporulation and clear readings on the first medium ( $\mathrm{M}$ a r c i n k ow s k a 1997).

Composition of species occurring on spring pea seeds ( $\mathrm{T} \mathrm{r} \mathrm{u} \mathrm{s} \mathrm{z} \mathrm{k} \mathrm{ow-}$ $\mathrm{s} \mathrm{k}$ a et al. 1968; M a r c i n k o w s k a 1998) and Austrian winter pea seeds was similar, especially for plant pathogenic fungi ( $\mathrm{M} \mathrm{a} \mathrm{r} \mathrm{c} \mathrm{in} \mathrm{k} \mathrm{ow} \mathrm{s} \mathrm{k} \mathrm{a}$ 1998). However, in the present study two more pea pathogens, i.e. $F$. oxysporum and $F$. solani, were isolated from seeds. These species had already been noted on edible pea seeds ( $\mathrm{C} z$ y ż e w s k a 1976 ; F i l i p o w i c z 1976; M a r c in k ow sk a 1993).

The fungi commonly occurring on spring pea seeds ( $\mathrm{M}$ a r c in $\mathrm{k} \mathrm{o}$ w$\mathrm{ska}$ 1998) were also present on the majority of the tested samples of fall-planted peas. The percentage of the common seed inhabitant differed for separate studies since genotypes, locations and years varied for them $(\mathrm{C} \mathrm{z}$ yżewska 1976; Filipowicz 1976; M a r c ink owska 1998). 


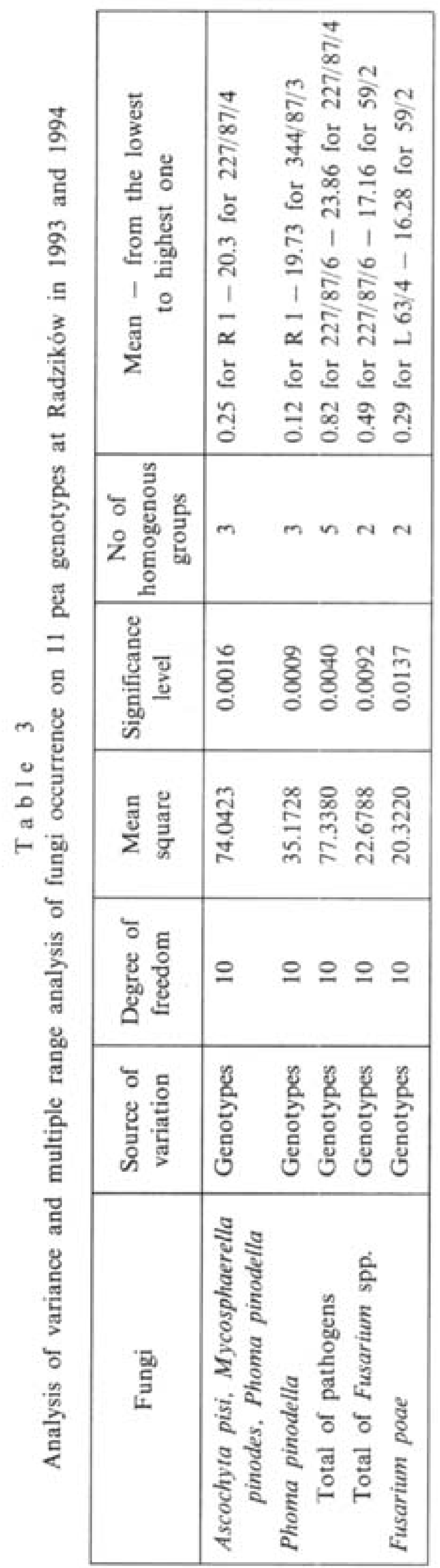



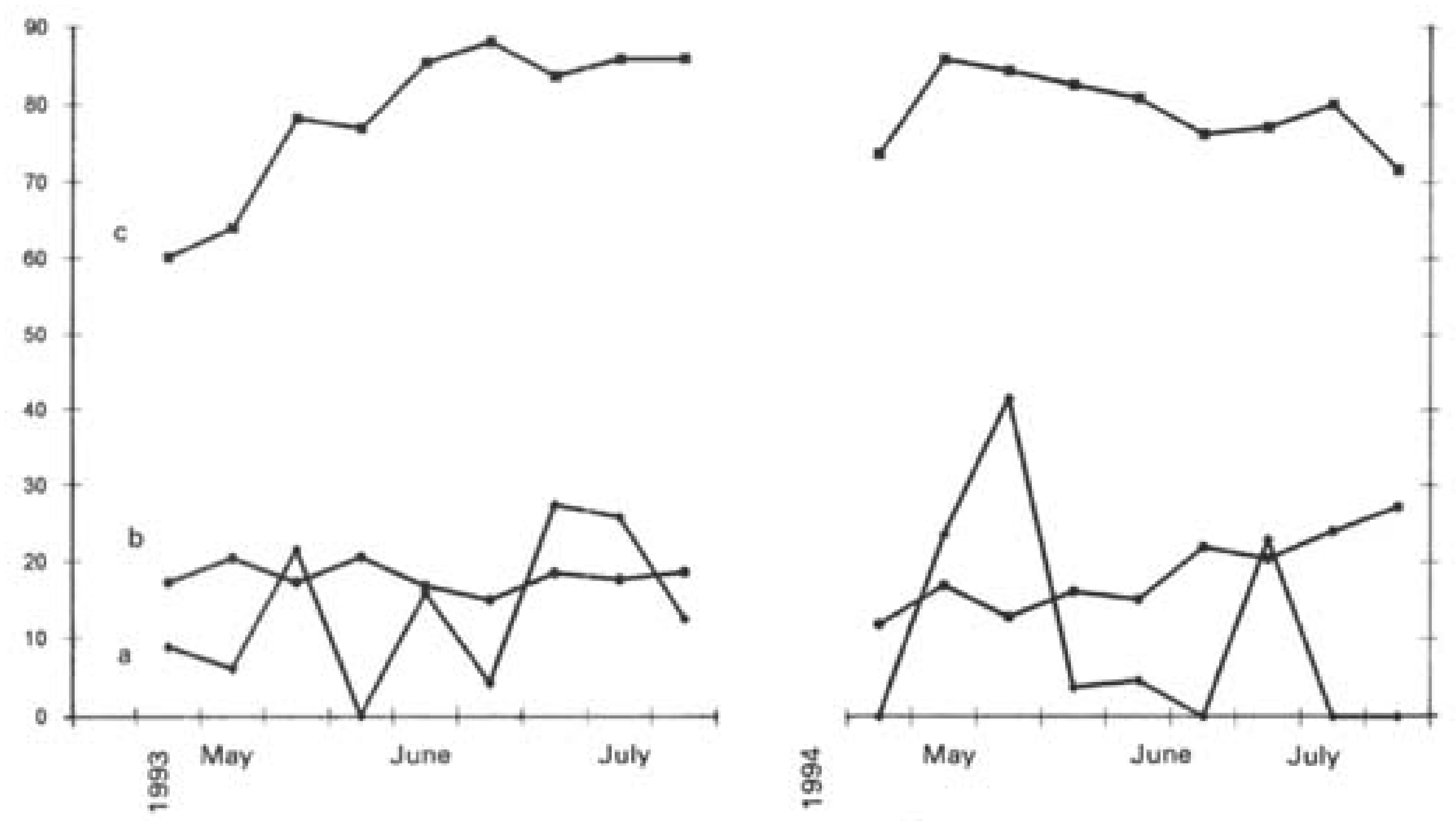

Fig. 1. Weather characteristics during 1993 and 1994 growing season (May, June, July) at Radzików

$a$ - total rainfall $(\mathrm{mm}), b$ - average daily air temperature $\left({ }^{\circ} \mathrm{C}\right), c$ - average humidity $(\%)$

Some investigations (C z y ż e w s k a 1976; M a r c i n k o w s k a 1998), revealed that $A$. alternata dominated on seeds while others ( $\mathrm{G} \mathrm{r} \mathrm{z} \mathrm{e} \mathrm{l} \mathrm{a} \mathrm{k,}$ I 1 a k ow i c z 1973; F i l i pow i c z 1976) -that. A. pisi. More recently $M$. pinodes and $P$. pinodella (B a t h gat e et al. $1989 ; \quad \mathrm{M}$ a $\mathrm{r}$ i nkowska, Szy rmer 1992; M a r c inkowska 1998) were found very often. In these studies $P$. pinodella was isolated from the highest percentage of seeds in 1994 while in $1993 \mathrm{M}$. pinodes, and $F$. poae. These differences resulted from genotype and enviroment variability as some genotype seeds were more frequently infested by the fungi in comparison to others. The weather of spring and early summer in 1993 and 1994 was quite similar but with heavier rainfalls in May 1994 and slightly higher RH in July 1993 (Fig. 1). These factors might have influenced the micromycetes but they were not statistically significant. In general, Austrian pea seed mycobiota was variable like on spring-planted peas, with the tendency of more common occurrence of $P$. pinodella reather than $A$. pisi or $M$. pinodes, the fungi responsible for ascochyta blight disease'. 


\section{REFERENCES}

Ali S. M, Nitsche L.F, Dube A.J., Krause M. R., Cameron B. 1978, Selection of pea lines for resistance to pathotypes of Ascochyta pinodes, A, fisi and Phoma medicaginis var. phodella. Aust. J. Agric. Res. 29: 841-849.

A $r x$ von J. A. 1974. The genera of fungi sporulating in pure culture, J. Cramer, Vaduz.

$\mathrm{B}$ a $\mathrm{thg}$ a t e A. S i vas it ha m p a r a m K., K ha $\mathrm{n}$ T. N. 1989. Identity and recovery of seed-borne fungal pathogens of field peas in Western Australial. N. Zeal. J. Crop. Hort. Sei. 17: 97-101.

B o o t h C. 1977. Laboratory guide to the identification of the major Fusariam species. C.M.I. Kew. Surrey.

CMI Descriptions of Pathogenic Fungi and Bacteria No. 150, 334, 340, 406, 431, 513.

$\mathrm{C} z$ y z e w $s \mathrm{k}$ a S. 1976. Studies on fungi infesting seeds of pea (Pisum sativum L). Biul. Warz. 19: $271-288$.

E11is M. B. 1971. Dematiaceous Hyphomycetes. CMI, Kew, Surrey.

Filip o w i c z A. J. 1976. Badania mikofory nasion grochu siewnego (Piswm sariwum L.) ze szczególnym uwzględnieniem grzybów z rodzaju Ascochyta i Fusarium. Roczn. Nauk Roln. ser. E 5 (2): 85-119.

G r z e I a k K. I 1 1 a k o w i c z A. 1973. Grzyby z rodzaju Ascochyza w laboratoryjnej ocenie zdrowotności nasion grochu (Pisum sativum L.). Biul. IHAR 3-4: 114-115.

K e r r A. 1963. The root rot Fusarium wilt complex of peas. Austral, J. Biol. Sci. 16: 55-59.

M a r c i n k o w s k a J. Z 1993. Fusarium spp. as pathogens of dry peas (Pisum sativam L.) in Poland. Hod. Rost. Aklim. Nasien. 37 (4): 95-102.

M a r c i n k o w s k J. 1998. Variability of dry seed mycobiota of Pisam satinum. Acta Mycol. (in print).

M a r c i n k o w s k a J. 1997. Diagnostyka sprawcow zgorrelowej plamistosci grochu. Biul. IHAR (in print).

Marcink owska J. Schollen berger M. 1979. Mikrolora nasion soi, Roczn. Nauk, Roln. ser. E, 9 (2) $41-54$.

M a r c i n k ow s k a J., S z y $\mathrm{r}$ m e r J. 1992. Etiologia zgorzeli siewek grochu ozimego (Pisum sativm L. var. arvense (L.) Poir.). Biul. IHAR 184: 89-92.

Noordeloos M. E, De Gruyter J., Van Ejjk G. W. Roeijmans H.J. 1993. Production of dendritic crystals in pure cultures of Phoma and Acsochyla and its value as a taxonomic character relative to morphology, pathology and cultural characteristics. Mycol. Res. 97 (11): 1343-1350.

Sk o $1 \mathrm{k}$ o A. J., G r o v e s J. W. W e 11 e n V. R. 1954. Ascochyra diseases of peas in Canada with special reference to seed transmision. Can. J. Agric. Sci. 34 (4): 417-428.

Truszkowska $W_{+4}$ Jasa $S_{4}$ Józefowicz M $M_{4}$ Usak P. 1968. Obserwacje mikroflory nasion niektórych roslin przechowywanych bez dostẹpu powietrat. Biul. IHAR $1968(1-2) \div 165-182$.

\section{Micromycetes nasion grochu zimującego}

Streszezenic

W 1993 roku badano wystepowanie grzybów na nasionach 8 genotypów grochu zimujłcego (Pisum satimum L. var, arvense (L) Poir.), zas w 1994 na nasionach 6 genotypow uprawianych w Radzikowic. W obydwu latach oceniano tylko nasiona odmiany Melrose oraz linii R 1 i R 2. Wyniki testu szalkowego na poźywce Coon'a wskazaly na wystepowanie Alternaria alternafa 
i Stemphylium botryosum we wszystkich próbach nasion. Phoma pinodella i Fusarium poae izolowane byly równie powszechnie tak jak: Botrytis cinerea, Sclerotinia sclerotiorum i Mycosphacrella pinodes, ale 3 ostatnie gatunki tylko w 1993 roku. Z kolei $F$. oxysporum, Trichothecium roseum i Ulocladium consortiale stwierdzono tylko na nasionach $\mathrm{z}$ pojedynczych prób. Liczba gatunków grzybów a także procent zasiedlonych przez nie nasion róźnil się w zależności od próby (rok, genotyp). Statystycznie udowodnione róznice stwierdzono pomiędzy genotypami dla sprawców askochytozy grochu (Ascochyta pisi, $M$. pinodes $P$. pinodella), gatunku $P$. pinodella, grzybów patogenicznych (A. pisi, $M$. pinodes, $P$. pinodella, B. cinerea, $F$, oxysporum, $F$, solani, Rhizoctonia solani, S. sclerotiorum) oraz gatunków rodzaju Fusarium i $F$. poae. Mikoflora nasion byla bogatsza w 1993 r. Na nasionach z poszczególnych genotypów przenoszone byly grzyby z 6-13 gatunków. Najwyzzzy procent $(33,84)$ nasion zasiedlonych przez $P$. pinodella stwierdzono w $1994 \mathrm{r}$. Sklad gatunkowy mikoflory nasion grochu zimującego byl podobny do stwierdzonego na nasionach $P$ sativum $z$ upraw wiosennych, zwłaszcza dla grzybów fitopatogenicznych. llościowe ich występowanic zmienialo sį̣ w zależności od genotypów i warunków otoczenia (pole doświadczalne, warunki atmosferyczne, rok). 